\title{
Nitrite-Phenol-NO Crosstalk: Phenol Oxidation and NO Generation from Nitrite at Copper(II) Sites
}

\author{
Zeinab Sakhaei, Subrata Kundu, Jeffery A. Bertke, Timothy H. Warren* \\ Department of Chemistry, Georgetown University, Box 571227-1227, Washington, D. C. 20057 United States
}

\section{Supporting Information Placeholder}

\begin{abstract}
Nitrite is involved in a plethora of biological phenomena that includes tyrosine nitration associated with neurodegenerative disorders and gastric phenol metabolism. Reaction of the $\beta$-diketiminato model complex $\left[\mathrm{Cl}_{2} \mathrm{NN}_{\mathrm{F} 6}\right] \mathrm{Cu}\left(\kappa^{2}-\mathrm{O}_{2} \mathrm{~N}\right)$ with phenols outlines the coupled generation of $\mathrm{NO}$ with phenol oxidation by nitrite at copper(II). Kinetic studies support nucleophilic attack of the hydroxyl group of phenols ArOH on the bound nitrite in $\left[\mathrm{Cu}^{\mathrm{II}}\right]\left(\kappa^{2}-\right.$ $\left.\mathrm{O}_{2} \mathrm{~N}\right)$ to give the copper(II) hydroxide $\left[\mathrm{Cu}^{\mathrm{II}}\right]-\mathrm{OH}$ along with the $O$-nitrosated phenol ArONO that ultimately leads to the corresponding biphenol or $o$-nitrophenol. The especially electron-rich antioxidant $\alpha$-tocopherol (vitamin E) quickly generates $\mathrm{NO}$ upon interaction with $\left[\mathrm{Cu}^{\mathrm{II}}\right]\left(\kappa^{2}-\mathrm{O}_{2} \mathrm{~N}\right)$. X-ray analysis of the oxidation products of the $\alpha$-tocopherol analogue PMC reveal formation of an elusive $O$-quinone methide bound to $\left[\mathrm{Cu}^{\mathrm{I}}\right]$, revealing two electron oxidation of PMC by $\left[\mathrm{Cu}^{\mathrm{II}}\right]\left(\kappa^{2}-\mathrm{O}_{2} \mathrm{~N}\right)$. These studies illustrate anaerobic pathways that generate NO from nitrite at copper(II) sites that result in phenol oxidation.
\end{abstract}

Nitrite $\left(\mathrm{NO}_{2}^{-}\right)$is an important reservoir of nitric oxide (NO) involved in a wide range of physiological activities such as neurotransmission, vasodilation, and immune response. ${ }^{1}$ While the enzyme NO-synthase (NOS) produces NO from Larginine by employing an $\mathrm{O}_{2}$ dependent route, ${ }^{2-3}$ reduction of nitrite to NO plays crucial role for tightly regulating NO concentrations in hypoxia. ${ }^{4-6}$ An imbalance in the production of NO under aerobic conditions leads to nitrosative stress which is associated with nitration and nitrosation of protein tyrosine residues ${ }^{7}$ that serves as both a biomarker for diseases such as cardiovascular, ${ }^{8}$ Alzhimer's, ${ }^{9}$ and Parkinson's, ${ }^{10}$ and mediator of pathogenic reactions involving phosphorylation and dephosphorylation with the nitrated protein becoming a target of degradation. ${ }^{7}$ " 11 Such modification also can interfere with signal transduction. ${ }^{7}$

In addition to oxidative mechanisms under inflammatory conditions, it has been recognized for quite some time that tyrosine nitr(os)ation (Scheme 1) can also occur by acidification of nitrite and nitrate such as occurs within acidic gastric environments after ingestion of $\mathrm{NO}_{2}^{-}$and $\mathrm{NO}_{3}^{-}$from dietary sources. ${ }^{12-13}$ This is also consistent with recent findings that dietary polyphenols enhance the reduction of nitrite to bio-
Scheme 1. Oxidation of Tyrosine in Presence of $\mathrm{NO} / \mathrm{NO}_{2}$

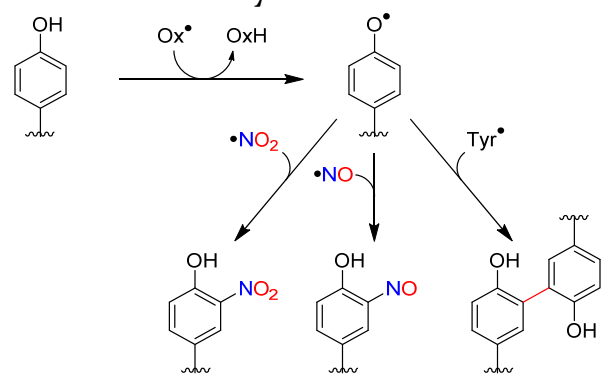

active NO in the acidic gastric lumen as an important part of the digestion process. ${ }^{14-15}$

Redox-active transition metals such as iron, copper, and manganese can catalyze the nitration of phenolic moieties by both peroxynitrite-dependent and peroxynitrite-independent pathways. ${ }^{16-17}$ Some of the better known examples include SOD,${ }^{17-18}$ peroxidases, ${ }^{19-20}$ and cytochrome $c$ oxidase which all possess copper containing active sites. ${ }^{21}$ Nitrite reduction at copper(II) has been extensively explored in the context of copper nitrite reductase that involves outer-sphere reduction to a copper(I) nitrite coupled with proton transfer. ${ }^{22}$ Indeed, a copper(I) complex of a proton-responsive ligand possessing acidic phenol moieties capable of $\mathrm{H}$-bonding results in rapid reduction of nitrite to $\mathrm{NO}$ with concomitant oxidation to copper(II). ${ }^{23}$ We have recently shown that copper(II) nitrites can oxidize nucleophiles such as phosphines and release NO upon $\mathrm{O}$-atom transfer, ${ }^{24}$ related to the reaction of nucleophiles with $[\mathrm{Fe}]-\mathrm{NO}_{2}$ complexes to give nitrosyls [Fe]-NO (Scheme 2A)..$^{25-27}$ Moreover, proton-assisted nucleophilic

\section{Scheme 2. NO Generation from Nitrite at Metal Sites}

O-atom transfer reactions of metal-nitrite complexes

A $[\mathrm{M}]-\mathrm{NO}_{2}+\mathrm{Nu} \longrightarrow[\mathrm{M}]+\bullet \mathrm{NO}+\mathrm{Nu}=\mathrm{O}$

$\mathrm{Nu}=\mathrm{PR}_{3}, \mathrm{SR}_{2}, \mathrm{RSH}$

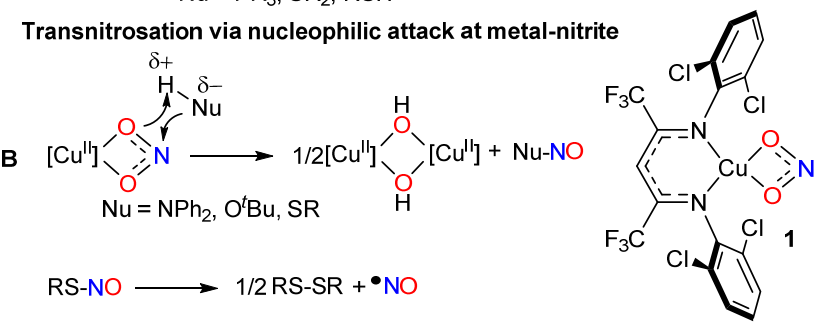

Phenol oxidation and NO generation: $O$-nitrosation and ArO-NO cleavage

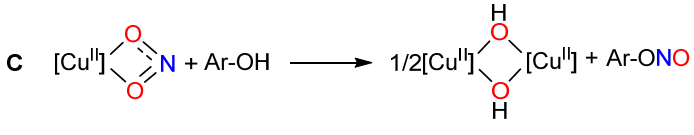


attack between copper(II) nitrites $\left[\mathrm{Cu}^{\mathrm{II}}\right]\left(\kappa^{2}-\mathrm{O}_{2} \mathrm{~N}\right)$ and nucleophiles $\mathrm{Nu}-\mathrm{H}$ gives [ $\left.\mathrm{Cu}^{\mathrm{II}}\right]-\mathrm{OH}$ and the nitrosated nucleophile $\mathrm{Nu}-\mathrm{NO}\left(\mathrm{Nu}=\mathrm{NPh}_{2}, \mathrm{O}^{\mathrm{t}} \mathrm{Bu}\right.$, and SR) (Scheme $\left.{ }_{2} \mathrm{~B}\right) .{ }^{28}$ In the case of thiols RS-H, $S$-nitrosothiols (RSNOs) form that provide a facile pathway for nitrite reduction to NO as RSNOs readily release NO to form disulfides RSSR.

Herein we describe the reaction of copper(II) nitrites with phenols $\mathrm{ArOH}$ to form $\mathrm{O}$-nitroso phenols ArONO that release $\mathrm{NO}$ (Scheme $2 \mathrm{C}$ ). Motivated by sparse experimental ${ }^{29}$ and computational ${ }^{30}$ studies on ArONO compounds, we demonstrate the interconversion of ArONO with the phenoxy radical $\mathrm{ArO} \cdot$ and $\mathrm{NO} \cdot$, clearly connecting ArONO formation with $\mathrm{NO}$ generation.

Recognizing the potential intermediacy of phenoxy radicals $\mathrm{ArO} \cdot$, we first investigated the reaction of 2,4,6-tri-tertbutylphenol $\left({ }^{t} \mathrm{Bu}_{3} \mathrm{ArOH}\right)$ with $\left[\mathrm{Cl}_{2} \mathrm{NN}_{\mathrm{F} 6}\right] \mathrm{Cu}\left(\kappa^{2}-\mathrm{O}_{2} \mathrm{~N}\right)$ (1) to discourage secondary phenol oxidation. The green color of $\left[\mathrm{Cl}_{2} \mathrm{NN}_{\mathrm{F} 6}\right] \mathrm{Cu}\left(\kappa^{2}-\mathrm{O}_{2} \mathrm{~N}\right)(\mathbf{1})$ quickly bleaches upon reaction with excess ${ }^{t} \mathrm{Bu}_{3} \mathrm{ArOH}$ (5o equiv.) in benzene at $\mathrm{RT}$ and leads to formation of a brownish-yellow precipitate of $\left\{\left[\mathrm{Cl}_{2} \mathrm{NN}_{\mathrm{F} 6}\right] \mathrm{Cu}\right\}_{2}(\mu-\mathrm{OH})_{2}(2)(82 \%$, based on gravimetric analysis) (Scheme 3 ). Through reaction of ${ }^{t} \mathrm{Bu}_{3} \mathrm{ArOH}$ with ${ }^{15} \mathrm{~N}$ labeled $\left[\mathrm{Cl}_{2} \mathrm{NN}_{\mathrm{F} 6}\right] \mathrm{Cu}\left(\kappa^{2}-\mathrm{O}_{2} \mathrm{~N}\right)\left(\mathbf{1}^{1-} \mathrm{N}\right),{ }^{t} \mathrm{Bu}_{3} \mathrm{ArONO}$ forms as identified by its ${ }^{15} \mathrm{~N}$ NMR signal at $\delta 387.0 \mathrm{ppm}$. Additionally, EPR spectroscopy clearly reveals the ${ }^{t} \mathrm{Bu}_{3} \mathrm{ArO} \cdot$ radical as a sharp signal at $g_{\text {iso }}=\mathbf{2 . 0 0}$. Analysis of the headspace gas indicates the presence of NO through chemical trapping with $\mathrm{Fe}(\mathrm{dtc})_{2}(\mathrm{dtc}=N, N$-diethyldithiocarbamate) (Figure S14).

Scheme 3. Reaction of $\left[\mathrm{Cu}^{\mathrm{II}}\right]\left(\kappa^{2}-\mathrm{O}_{2} \mathrm{~N}\right)$ with ${ }^{\mathrm{tBu}}{ }^{\mathrm{A}} \mathrm{ArOH}$ : ${ }^{\mathrm{t}} \mathrm{Bu}_{3} \mathrm{ArONO} /{ }^{\mathrm{t}} \mathrm{Bu}_{3} \mathrm{ArO} \cdot+\mathrm{NO}$ Equilibrium
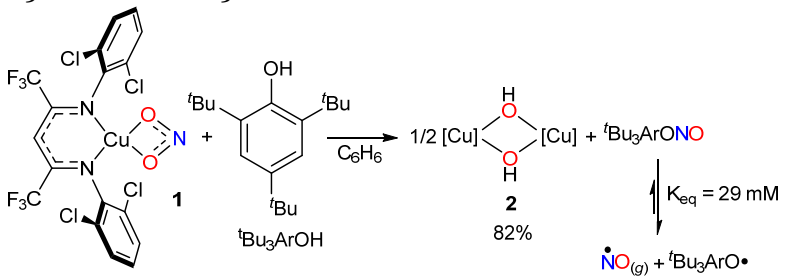

Control experiments reveal that ${ }^{t} \mathrm{Bu}_{3} \mathrm{ArONO}$ is the source of both the ${ }^{t} \mathrm{Bu}_{3} \mathrm{ArO} \cdot$ radical as well as NO. Reaction of ${ }^{t} \mathrm{BuO}^{15} \mathrm{NO}$ with ${ }^{t} \mathrm{Bu}_{3} \mathrm{ArOH}$ provides ${ }^{t} \mathrm{Bu}_{3} \mathrm{ArO}^{15} \mathrm{NO}$ observed by ${ }^{15} \mathrm{~N}$ NMR spectroscopy as well as generates the ${ }^{t} \mathrm{Bu}_{3} \mathrm{ArO} \cdot$ radical evidenced by EPR ( $\mathrm{g}=\mathbf{2 . 0 0}$ ) as well as UV-vis spectroscopy $\left(\lambda_{\max }=626 \mathrm{~nm}\left(328 \mathrm{M}^{-1} \mathrm{~cm}^{-1}\right)\right)$. Sampling of the headspace also reveals formation of $\mathrm{NO}$ in $73 \%$ yield as detected by chemical trapping with [T(O-Me)PP]Co ${ }^{\mathrm{II}}$ (Figures $\left.\mathrm{S}_{1}-\mathrm{S}_{5}\right)$. Employing UV-vis spectroscopy, the equilibrium constant $\mathrm{K}_{\mathrm{eq}}=29 \mathrm{mM}$ in benzene at RT may be determined for loss of $\mathrm{NO}$ from ${ }^{t} \mathrm{Bu}_{3} \mathrm{ArONO}$ to give ${ }^{t} \mathrm{Bu}_{3} \mathrm{ArO} \cdot$ at (Figure S9).

With oxidizable phenols, a more complex reaction mixture ensues. Reaction between $\left[\mathrm{Cl}_{2} \mathrm{NN}_{\mathrm{F} 6}\right] \mathrm{Cu}\left(\kappa^{2}-\mathrm{O}_{2} \mathrm{~N}\right)(\mathbf{1})$ and $2,4^{-}$ di-tert-butylphenol (2,4-DTBP) (50 equiv.) in benzene at room temperature quickly provides a precipitate of $\left\{\left[\mathrm{Cl}_{2} \mathrm{NN}_{\mathrm{F} 6}\right] \mathrm{Cu}\right\}_{2}(\mu-\mathrm{OH})_{2}(\mathbf{2})(72 \%)$ and headspace analysis indicates formation of NO in $99 \%$ yield. GC-MS analysis reveals the corresponding biphenol (5) as the major phenolbased product along with a small amount (6\%) of 2,4-di-tert- butyl-6-nitrophenol (7). Although we anticipated the initial formation of 2,4-di-tert-butyl-6-nitrosophenol (6) under these conditions (Scheme 4 ), nitro compound 7 also forms in small amounts in the reaction of 2,4 -DTBP with ${ }^{t} \mathrm{BuONO}$ under anaerobic conditions (Scheme S10). The corresponding biphenol $\mathbf{5}$ actually forms in greater than $100 \%$ stoichiometric yield due to subsequent oxidation of 2,4 -DTBP by $[\mathrm{Cu}]_{2}(\mu-$ $\mathrm{OH})_{2}(2)$ shown in an independent experiment (Figure S21).

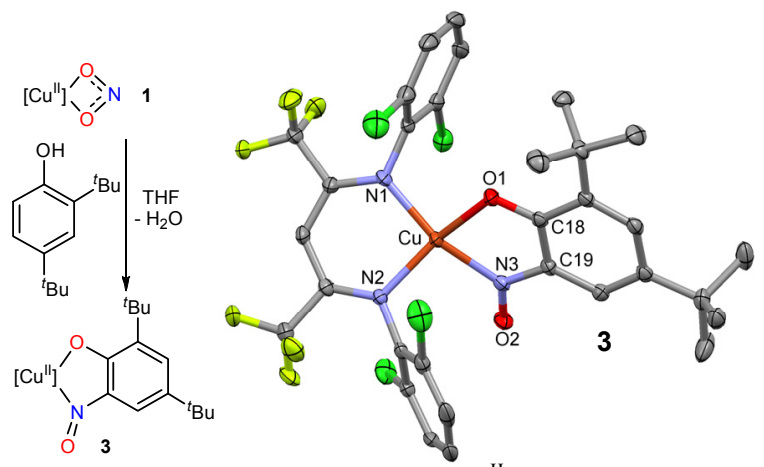

Figure 1. Synthesis and structure of $\left[\mathrm{Cu}^{\mathrm{II}}\right]\left(\kappa^{2}-\mathrm{O}, \mathrm{N}-\mathrm{OArNO}\right)(3)$.

The reaction between 2,4 -DTBP and $\left[\mathrm{Cu}^{\mathrm{II}}\right]\left(\kappa^{2}-\mathrm{O}_{2} \mathrm{~N}\right)(\mathbf{1})$ is highly solvent dependent. In THF, we isolate the copper(II) nitrosophenolate $\left[\mathrm{Cl}_{2} \mathrm{NN}_{\mathrm{F} 6}\right] \mathrm{Cu}\left(\kappa^{2}-\mathrm{O}, \mathrm{N}-\mathrm{OArNO}\right)$ (3) in $84 \%$ yield. Single crystal X-ray diffraction analysis displays a square planar copper core bound by the $\kappa^{2}-\mathrm{O}, \mathrm{N}$ moiety to the oxidized $C$-nitroso phenol resulting from nitrosation of $2,4^{-}$ DTBP molecule (Figure 1). The distances between the $\mathrm{Cu}$ center and nitroso phenol (Cu1-O1 $=1.9495(13), \mathrm{Cu}_{1}-\mathrm{N}_{3}$ $=1.9847(17) \AA$ ) are in the same range as $\mathrm{Cu}-\mathrm{N}_{\beta}$ distances (Cu1$\left.\mathrm{N}_{1}=1.9475(17), \mathrm{Cu}_{1}-\mathrm{N}_{2}=1.9548(16) \AA ̊ \AA\right)$. The UV-vis absorption spectrum of complex 3 in THF depicts two intense features centered at $\lambda_{\max }=550 \mathrm{~nm}\left(2510 \mathrm{M}^{-1} \mathrm{~cm}^{-1}\right)$ and $645 \mathrm{~nm}$ $\left(1750 \mathrm{M}^{-1} \mathrm{~cm}^{-1}\right)$. The isotropic X-band EPR spectrum of 3 at $293 \mathrm{~K}$ in tetrahydrofuran shows a four line signal centered at $g_{\text {iso }}=2.070$ with $A_{\text {iso }}(\mathrm{Cu})=172 \mathrm{MHz}$, confirming its formulation as a copper(II), $S=1 / 2$ species (Figure $\mathrm{S}_{35}$ ). GC-MS analysis of the reaction mixture shows a different partitioning of products in different solvents. In benzene, biphenol and NO are formed with little 2,4-di-tert-butyl-6-nitrophenol (7) whereas in THF the biphenol $\mathbf{5}$ is a minor product. Copper complex 3 likely forms in an acid-base reaction from 2,4-ditert-butyl-6-nitrosophenol (6) (perhaps initially formed from $\mathrm{ArO} \cdot$ and $\mathrm{NO} \cdot)$ and $[\mathrm{Cu}]_{2}(\mu-\mathrm{OH})_{2}(\mathbf{2})$ in THF (Scheme 4$)$.

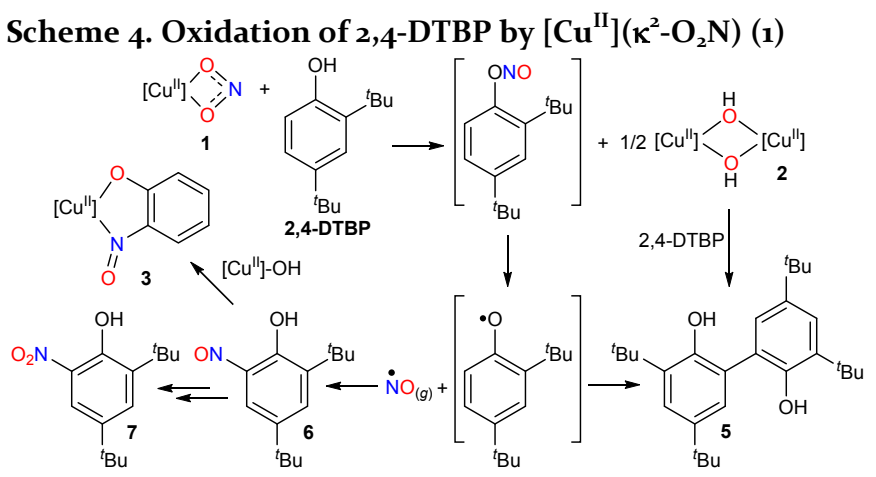




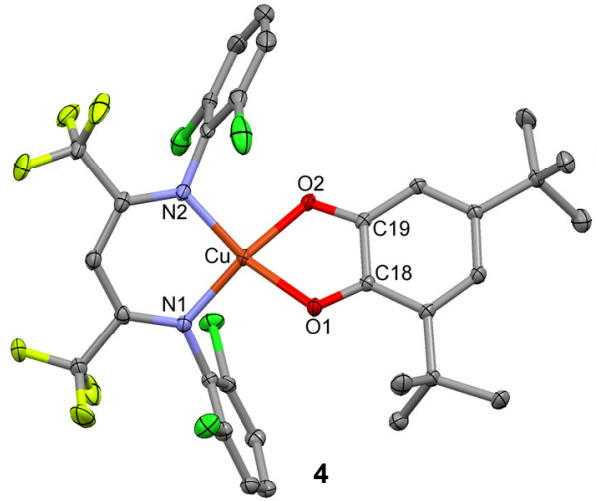

Figure 2. X-ray structures of $\left[\mathrm{Cu}^{\mathrm{II}}\right]\left(\kappa^{2}-\mathrm{O}, \mathrm{O}^{\prime}-3,5\right.$-di-tert-butyl-o-semiquinone $)$ $\left[\mathrm{Cu}^{\mathrm{I}}\right]_{2}\left(\mu-\eta^{2}: \kappa^{1}-\mathrm{PMC}-2 \mathrm{H}\right)(\mathbf{9})$.

In addition to aromatic phenols with single $\mathrm{OH}$ moieties, we investigated the reaction of $\left[\mathrm{Cl}_{2} \mathrm{NN}_{\mathrm{F} 6}\right] \mathrm{Cu}\left(\kappa^{2}-\mathrm{O}_{2} \mathrm{~N}\right)(\mathbf{1})$ with 3,5-di-tert-butylcatechol as it emulates the interactions of polyphenols with nitrite at copper(II) sites (Scheme 5). An equimolar reaction between 3,5-di-tert-butylcatechol and $\mathbf{1}$ in benzene at room temperature leads to an immediate color change from green to dark brown with concomitant evolution of $\mathrm{NO}$ gas in $75 \%$ yield. The dark green complex 4 can be isolated in $98 \%$ yield, revealed by X-ray crystallography as a $\beta$-diketiminato copper fragment $\left[\mathrm{Cl}_{2} \mathrm{NN}_{\mathrm{F} 6}\right] \mathrm{Cu}$ bound to $3,5^{-}$ di-tert-butyl-o-benzoquinone moiety in a $\kappa^{2}-O, O^{\prime}$ fashion with $\mathrm{Cu}-\mathrm{N}_{\beta \text {-dik }}=1.9361(13), 1.9323(12) \AA$ and $\mathrm{Cu}-\mathrm{O}=1.9330(11)$, $1.9527(10) \AA$ (Figure 2, S39). The sum of the angles around the $\mathrm{Cu}$ center in 4 is $369.43(17)^{\circ}$, hence demonstrating a distorted square planar geometry at the copper center. Complex 4 is paramagnetic and provides a solution magnetic moment of $2.54 \mathrm{BM}$ in benzene- $d_{6}$ at $300 \mathrm{~K}$, thereby suggesting a formulation that involves ferromagnetic coupling between a $\mathrm{Cu}^{\mathrm{II}}$ center and a semiquinone radical anion.

Scheme 5. NO Generation from a Substituted Catechol

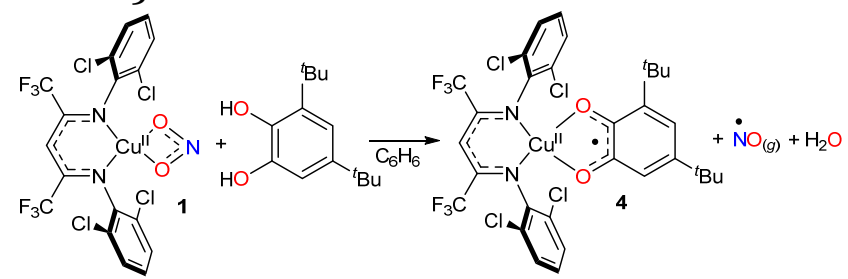

Pseudo first-order rate constants for the reaction of $\left[\mathrm{Cu}^{\mathrm{II}}\right]\left(\kappa^{2}-\mathrm{O}_{2} \mathrm{~N}\right)(\mathbf{1})$ with excess 2,4 -DTBP $(25-60$ equiv.) in benzene at $30{ }^{\circ} \mathrm{C}$ were obtained by observing the loss of the UV-vis band of 1 at $\lambda=610 \mathrm{~nm}$ which provides the rate law: rate $=k\left[\mathrm{Cu}^{\mathrm{II}}\left(\kappa^{2}-\mathrm{O}_{2} \mathrm{~N}\right)\right][\mathrm{HOAr}]$ with $k=6.3(1) \times 10^{-2} \mathrm{M}^{-1} \mathrm{~s}^{-1}$ (Figure S22). This reaction exhibits a negligible kinetic isotope effect $(\mathrm{KIE}=0.97$ ) when employing HOAr' and DOAr' $\left(A r^{\prime}=2,4{ }^{t}{ }^{t} u_{2} \mathrm{C}_{6} \mathrm{H}_{3}\right.$ ) (Figure $\mathrm{S}_{24}$ ), indicating that proton transfer is not an important part of (or up to) the rate determining step. Eyring analysis gives $\Delta \mathrm{G}^{\ddagger}=19.2$ (9) with $\Delta \mathrm{H}^{\ddagger}=$ 16.4(7) and $\Delta S^{*}=-9.3(24)$ eu.

Hammett studies on the reaction of $\left[\mathrm{Cl}_{2} \mathrm{NN}_{\mathrm{F} 6}\right] \mathrm{Cu}\left(\kappa^{2}-\mathrm{O}_{2} \mathrm{~N}\right)$ (1) with a modest range of $p$-substituted phenols in benzene at $30{ }^{\circ} \mathrm{C}$ provides $\rho=-1.6(1)$ indicating faster rates with electron-rich phenols (Figure $3 \mathrm{~A}$ ). Accordingly, making the nitrite less electrophilic should also result in a lower rate. Reaction of 2,4-DTBP with $\left[\mathrm{Me}_{2} \mathrm{NN}_{\mathrm{F} 6}\right] \mathrm{Cu}\left(\kappa^{2}-\mathrm{O}_{2} \mathrm{~N}\right)(\mathbf{1 a})\left(\mathrm{E}_{1 / 2}=230\right.$ $\mathrm{mV}$ vs. NHE in THF) that is somewhat more electron-rich than $\left[\mathrm{Cl}_{2} \mathrm{NN}_{\mathrm{F} 6}\right] \mathrm{Cu}\left(\kappa^{2}-\mathrm{O}_{2} \mathrm{~N}\right)(\mathbf{1})\left(\mathrm{E}_{1 / 2}=330 \mathrm{mV}\right)$ results in a second-order rate constant $k=6.4(6) \times 10^{-3} \mathrm{M}^{-1} \mathrm{~s}^{-1}$ at $30{ }^{\circ} \mathrm{C}$ that is an order of magnitude slower than the corresponding $k=$ $6.3(1) \times 10^{-2} \mathrm{M}^{-1} \mathrm{~s}^{-1}$ for 1 (Figure $3 \mathrm{~B}$ ). Taken together, these observations support a mechanism that involves nucleophilic attack by the phenol on an electrophilic nitrite at copper(II) (Scheme $2 \mathrm{~B}$ ).

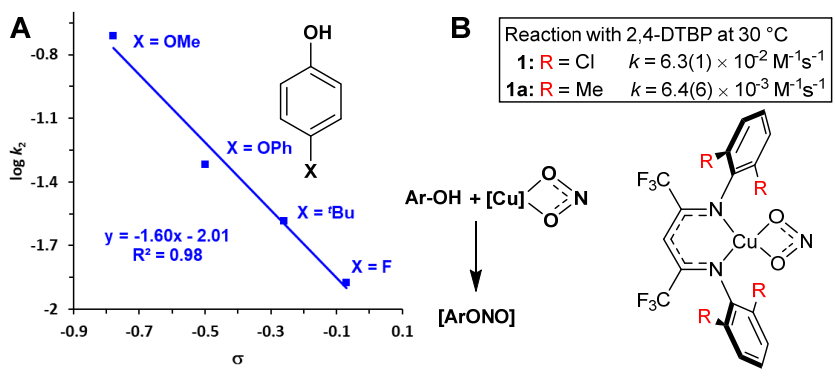

Figure 3. (A) Hammett plot illustrating rate acceleration with electron-rich phenols and (B) comparison of rate constants that indicate faster reaction at electron-poor copper(II) nitrite.

Since the rate of phenol reaction with $\left[\mathrm{Cu}^{\mathrm{II}}\right]\left(\kappa^{2}-\mathrm{O}_{2} \mathrm{~N}\right)(\mathbf{1})$ increases through the use of electron-rich phenols, we considered the reaction with the antioxidant $\alpha$-tocopherol (vitamin E) and its synthetic analogue PMC which are extraordinarily electron-rich phenols. $\alpha$-tocopherol and PMC react with 1 to generate $\mathrm{NO}$ in $73 \%$ and $88 \%$ yield, respectively (Scheme 6A). Kinetic studies suggest that PMC reacts with 1 at a rate that is orders of magnitude faster than 2,4-DTBP at $30{ }^{\circ} \mathrm{C}$, prompting us to examine the reaction at $-40{ }^{\circ} \mathrm{C}$. At this temperature, monitoring the growth of a low energy

Scheme 6. NO Generation from Vitamin E Analogues and Formation of o-Quinone Methide Derivatives 8 and 9

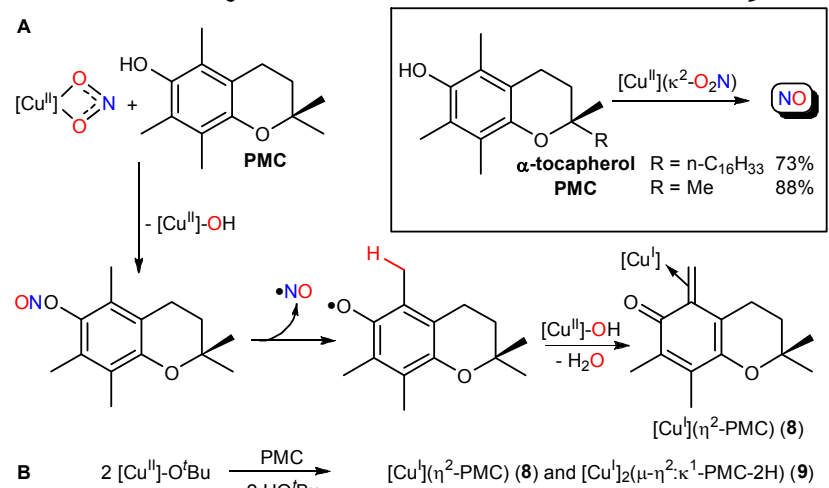


band at $\lambda=1050 \mathrm{~nm}$ allows us to assign the rate law: rate $=$ $k\left[\mathrm{Cu}^{\mathrm{II}}\left(\kappa^{2}-\mathrm{O}_{2} \mathrm{~N}\right)\right][\mathrm{PMC}]$ with $k=9.9(6) \times 10^{-3} \mathrm{M}^{-1} \mathrm{~s}^{-1}$ (Figure $\mathrm{S}_{31}$ ). Extrapolating the second-order rate constant for the reaction of 1 with 2,4-di-tert-butylphenol at $-40{ }^{\circ} \mathrm{C}$ via the Eyring analysis gives $k=1.7 \times 10^{-5} \mathrm{M}^{-1} \mathrm{~s}^{-1}$. Thus, PMC reacts almost 3 orders of magnitude faster than 2,4-DTBP!

To further probe the nature of the low temperature intermediate that forms in the reaction of PMC with $\left[\mathrm{Cu}^{\mathrm{II}}\right]\left(\mathrm{k}^{2}-\right.$ $\left.\mathrm{O}_{2} \mathrm{~N}\right)(\mathbf{1})$, we added PMC to a solution of the corresponding $\left[\mathrm{Cu}^{\mathrm{II}}\right]-\mathrm{O}^{t} \mathrm{Bu}$ complex in pentane at $-40{ }^{\circ} \mathrm{C}$ which quickly generates the species with $\lambda=1050 \mathrm{~nm}$ (Scheme 6B, Figures S31, $\mathrm{S}_{32}$ ). From these pentane solutions, we were fortunate to isolate a few crystals of two different copper complexes characterized by X-ray that each feature a doubly oxidized PMC ligand in $\left[\mathrm{Cu}^{\mathrm{I}}\right]\left(\eta^{2}-\mathrm{PMC}-2 \mathrm{H}\right)(8)$ and $\left[\mathrm{Cu}^{\mathrm{I}}\right]_{2}\left(\mu-\eta^{2}: \kappa^{1}-\mathrm{PMC}-2 \mathrm{H}\right)$ (9) (Figure 2). The $\mathrm{C}_{2} 6-\mathrm{C}_{31}(8: 1.385(5), 9: 1.387(7) \AA)$ and C-O (8: 1.247(4), 9: 1.238(6) ̊̊) bond distances reflect the $\mathrm{C}=\mathrm{C}$ and $\mathrm{C}=\mathrm{O}$ bonds within the $\mathrm{o}$-quinoid methide structure of copper(I) adducts 8 and 9 (Scheme 6A). Unfortunately the sensitivity of $\mathbf{8}$ and $\mathbf{9}$ hampered additional solution characterization. Such o-quinone methides are key intermediates in vitamin E metabolism which have been spectroscopically observed via trapping experiments, ${ }^{31-32}$ but have eluded previous X-ray characterization due to their short lifetimes. Thus, $\alpha$-tocopherol quickly generates NO upon reaction with copper(II) nitrite 1, ultimately undergoing a two-electron oxidation to an o-quinoid methide at low temperature.

Phenols generate NO from nitrite at copper(II) via oxidation of the phenol to $O$-nitrosated intermediates ArONO susceptible to NO loss to give the phenoxy radical ArOMechanistic studies suggest a proton-assisted nucleophilic attack of the phenol on an electrophilic copper(II) nitrite with highest rates for electron-rich phenols. Accordingly, phenolic antioxidants such as $\alpha$-tocopherol react very quickly with copper(II) bound nitrite to generate NO. They undergo 2-electron oxidation to highly reactive o-quinone methides that may be captured via $\eta^{2}$-methide coordination to the resulting copper(I) center. These studies underscore anaerobic pathways for phenol oxidation that complement peroxynitrite-dependent modifications that often take place under aerobic conditions. ${ }^{7}$

\section{ASSOCIATED CONTENT}

\section{Supporting Information}

This material is available free of charge via the Internet at http://pubs.acs.org. Experimental, characterization, and computational details (PDF)

X-ray crystallographic data of 1a, 3, 4, 8, and 9 (CIF).

\section{AUTHOR INFORMATION}

\section{Corresponding Author}

* thw@georgetown.edu

\section{Notes}

The authors declare no competing financial interests.

\section{ACKNOWLEDGMENT}

THW thanks the National Institutes of Health (Ro1GM126205). THW and SK are grateful to the
Georgetown Environmental Initiative for additional support of this work. We thank Prof. Ken Karlin for use of an EPR spectrometer at Johns Hopkins University.

\section{REFERENCES}

1. Maia, L. B.; Moura, J. J. G., How Biology Handles Nitrite. Chem. Rev. 2014, 114, 5273-5357.

2. Gladwin, M. T.; Schechter, A. N.; Kim-Shapiro, D. B.; Patel, R. P.; Hogg, N.; Shiva, S.; Cannon, R. O.; Kelm, M.; Wink, D. A.; Espey, M. G.; Oldfield, E. H.; Pluta, R. M.; Freeman, B. A.; Lancaster, J. R.; Feelisch, M.; Lundberg, J. O., The emerging biology of the nitrite anion. Nat. Chem. Biol. 2005, 1, 308-314.

3. Lundberg, J. O.; Weitzberg, E.; Gladwin, M. T., The nitratenitrite-nitric oxide pathway in physiology and therapeutics. Nat. Rev. Drug Discovery 2008, 7, 156-167.

4. Cosby, K.; Partovi, K. S.; Crawford, J. H.; Patel, R. P.; Reiter, C. D.; Martyr, S.; Yang, B. K.; Waclawiw, M. A.; Zalos, G.; Xu, X. L.; Huang, K. T.; Shields, H.; Kim-Shapiro, D. B.; Schechter, A. N.; Cannon, R. O.; Gladwin, M. T., Nitrite reduction to nitric oxide by deoxyhemoglobin vasodilates the human circulation. Nat. Med. 2003, 9, 1498-1505.

5. Hendgen-Cotta, U. B.; Merx, M. W.; Shiva, S.; Schmitz, J.; Becher, S.; Klare, J. P.; Steinhoff, H. J.; Goedecke, A.; Schrader, J.; Gladwin, M. T.; Kelm, M.; Rassaf, T., Nitrite reductase activity of myoglobin regulates respiration and cellular viability in myocardial ischemia-reperfusion injury. Proc. Natl. Acad. Sci. U. S. A. 2008, 105, 10256-10261.

6. Hematian, S.; Kenkel, I.; Shubina, T. E.; Duerr, M.; Liu, J. J.; Siegler, M. A.; Ivanovic-Burmazovic, I.; Karlin, K. D., Nitrogen Oxide Atom-Transfer Redox Chemistry; Mechanism of $\mathrm{NO}(\mathrm{g})$ to Nitrite Conversion Utilizing mu-oxo Heme-Fe-III-OCu-II(L) Constructs. J. Am. Chem. Soc. 2015, 137, 6602-6615.

7. Ferrer-Sueta, G.; Campolo, N.; Trujillo, M.; Bartesaghi, S.; Carballa, S.; Romero, N.; Alvarez, B.; Radi, R., Biochemistry of Peroxynitrite and Protein Tyrosine Nitration. Chem. Rev. 2018, 118, 1338-1408.

8. Shishehbor, M. H.; Aviles, R. J.; Brennan, M. L.; Fu, X.; Goormastic, M.; Pearce, G. L.; Gokce, N.; Keaney, J. F., Jr.; Penn, M. S.; Sprecher, D. L.; Vita, J. A.; Hazen, S. L., Association of nitrotyrosine levels with cardiovascular disease and modulation by statin therapy. J. Am. Med. Assoc. 2003, 289, 1675-1680.

9. Good, P. F.; Werner, P.; Hsu, A.; Olanow, C. W.; Perl, D. P., Evidence of neuronal oxidative damage in Alzheimer's disease. Am. J. Pathol. 1996, 149, 21-28.

10. Danielson, S. R.; Held, J. M.; Schilling, B.; Oo, M.; Gibson, B. W.; Andersen, J. K., Preferentially increased nitration of alphasynuclein at tyrosine-39 in a cellular oxidative model of Parkinson's disease. Anal. Chem. 2009, 81, 7823-7828.

11. Souza, J. M.; Choi, I.; Chen, Q.; Weisse, M.; Daikhin, E.; Yudkoff, M.; Obin, M.; Ara, J.; Horwitz, J.; Ischiropoulos, H., Proteolytic degradation of tyrosine nitrated proteins. Arch. Biochem. Biophys. 2000, 380, 360-366.

12. Knight, T. M.; Forman, D.; Ohshima, H.; Bartsch, H., Endogenous Nitrosation of L-Proline by Dietary-Derived Nitrate. Nutr. Cancer 1991, 15, 195-203.

13. van der Vliet, A., Tyrosine nitration: who did it, and how do we prove it? A commentary on " $\mathrm{pH}$ dependent nitration of parahydroxyphenylacetic acid in the stomach". Free Radical Biol. Med. 2006, 41, 869-871.

14. Lundberg, J. O.; Gladwin, M. T.; Weitzberg, E., Strategies to increase nitric oxide signalling in cardiovascular disease. Nat. Rev. Drug Discovery 2015, 14, 623-641. 
15. Gago, B.; Lundberg, J. O.; Barbosa, R. M.; Laranjinha, J., Red wine-dependent reduction of nitrite to nitric oxide in the stomach. Free Radical Biol. Med. 2007, 43, 1233-1242.

16. Campolo, N.; Bartesaghi, S.; Radi, R., Metal-catalyzed protein tyrosine nitration in biological systems. Redox Rep. 2014, 19, 221-231.

17. Ischiropoulos, H.; Zhu, L.; Chen, J.; Tsai, M.; Martin, J. C.; Smith, C. D.; Beckman, J. S., Peroxynitrite-mediated tyrosine nitration catalyzed by superoxide dismutase. Arch. Biochem. Biophys. 1992, 298, 431-437.

18. Beckman, J. S.; Ischiropoulos, H.; Zhu, L.; van der Woerd, M.; Smith, C.; Chen, J.; Harrison, J.; Martin, J. C.; Tsai, M., Kinetics of superoxide dismutase- and iron-catalyzed nitration of phenolics by peroxynitrite. Arch. Biochem. Biophys. 1992, 298, 438-445.

19. Floris, R.; Piersma, S. R.; Yang, G.; Jones, P.; Wever, R., Interaction of myeloperoxidase with peroxynitrite. A comparison with lactoperoxidase, horseradish peroxidase and catalase. Eur. $J$. Biochem. 1993, 215, 767-775.

20. Sampson, J. B.; Rosen, H.; Beckman, J. S., Peroxynitritedependent tyrosine nitration catalyzed by superoxide dismutase, myeloperoxidase, and horseradish peroxidase. Methods Enzymol. 1996, 269, 210-218.

21. Castro, L.; Eiserich, J. P.; Sweeney, S.; Radi, R.; Freeman, B. A., Cytochrome c: a catalyst and target of nitrite-hydrogen peroxide-dependent protein nitration. Arch. Biochem. Biophys. 2004, 421, 99-107.

22. Merkle, A. C.; Lehnert, N., Binding and activation of nitrite and nitric oxide by copper nitrite reductase and corresponding model complexes. Dalton Trans. 2012, 41, 3355-3368.

23. Moore, C. M.; Szymczak, N. K., Nitrite reduction by copper through ligand-mediated proton and electron transfer. Chem. Sci. 2015, 6, 3373-3377.
24. Sakhaei, Z.; Kundu, S.; Donnelly, J. M.; Bertke, J. A.; Kim, W. Y.; Warren, T. H., Nitric oxide release via oxygen atom transfer from nitrite at copper(II). Chem. Commun. 2017, 53, 549552.

25. Heinecke, J.; Ford, P. C., Formation of Cysteine Sulfenic Acid by Oxygen Atom Transfer from Nitrite. J. Am. Chem. Soc. 2010, 132, 9240-9243.

26. Heinecke, J. L.; Khin, C.; Pereira, J. C. M.; Suarez, S. A.; Iretskii, A. V.; Doctorovich, F.; Ford, P. C., Nitrite Reduction Mediated by Heme Models. Routes to NO and HNO? J. Am. Chem. Soc. 2013, 135, 4007-4017.

27. Tsai, F. T.; Lee, Y. C.; Chiang, M. H.; Liaw, W. F., Nitrateto-Nitrite-to-Nitric Oxide Conversion Modulated by NitrateContaining $\{\mathrm{Fe}(\mathrm{NO})(2)\}(9)$ Dinitrosyl Iron Complex (DNIC). Inorg. Chem. 2013, 52, 464-473.

28. Kundu, S.; Kim, W. Y.; Bertke, J. A.; Warren, T. H., Copper(II) Activation of Nitrite: Nitrosation of Nucleophiles and Generation of NO by Thiols. J. Am. Chem. Soc. 2017, 139, 10451048.

29. Daiber, A.; Mehl, M.; Ullrich, V., New aspects in the Reaction Mechanism of Phenol with Peroxynitrite: The Role of Phenoxy Radicals. Nitric Oxide-Biol. Ch. 1998, 2, 259-269.

30. Gao, Z. Q.; Yang, M.; Tang, C. L.; Yang, F. Y.; Fan, X. S.; Yang, R.; Huang, Z. H., Ab Initio Calculation for Isomerization Reaction Kinetics of Nitrobenzene Isomers. Chem. Phys. Lett. 2019, 715, 244-251.

31. Rosenau, T.; Potthast, A.; Elder, T.; Kosma, P., Stabilization and first direct spectroscopic evidence of the o-quinone methide derived from vitamin E. Org. Lett. 2002, 4, 4285-4288.

32. Marteau, C.; Favier, D.; Nardello-Rataj, V.; Aubry, J. M., Dramatic Solvent Effect on the Synergy between Alphatocopherol and BHT Antioxidants. Food Chem. 2014, 160, 190195. 